J. Dairy Sci. 98:6939-6953

http://dx.doi.org/10.3168/jds.2015-9518

(C) American Dairy Science Association ${ }^{\circledR}, 2015$.

\title{
Diets rich in starch improve the efficiency of amino acids use by the mammary gland in lactating Jersey cows
}

\author{
G. Cantalapiedra-Hijar, ${ }^{* 1}$ I. Ortigues-Marty, ${ }^{*}$ and S. Lemosquet†‡ \\ *Institut National de la Recherche Agronomique, UMR 1213 INRA-VetAgroSup, Unité Mixte de Recherches sur les Herbivores, \\ 63122 St Genès Champanelle, France \\ †INRA, UMR 1348 PEGASE, F-35590 Saint-Gilles, France \\ ‡Agrocampus Ouest, UMR1348 PEGASE, F-35000 Rennes, France
}

\begin{abstract}
The objective of this study was to test whether the greater milk $\mathrm{N}$ yield usually observed when feeding diets based on starch versus fiber was the consequence of a higher efficiency of AA use across the mammary gland and whether this effect depended on dietary crude protein $(\mathrm{CP})$ content. Five midlactation multicatheterized Jersey cows were fed 4 isoenergetic diets to provide 2 different carbohydrate compositions $(\mathrm{CHO}$; rich in starch vs. rich in fiber) crossed by 2 different protein levels (12.0 vs. $16.5 \% \mathrm{CP}$ ) and according to a $4 \times 4$ Latin square design. Blood samples were collected at the end of each treatment period from the mesenteric artery and mammary vein to determine mammary net nutrient fluxes. The nature of nutrients taken up by the mammary gland differed between starch and fiber diets: mammary net uptake of acetate increased with fiber versus starch diets, whereas mammary net uptake and clearance rate of glucose increased with starch versus fiber diets but only at a normal CP level. In addition, the mammary net uptake of total, essential, and branched-chain AA (BCAA) was significantly enhanced $(12,11$, and $26 \%$ on average, respectively) when feeding starch versus fiber diets, in line with a greater milk protein yield ( $7 \%$ on average) and regardless of the CP level. The conversion efficiency of plasma essential AA into milk protein was improved with starch diets (33.7\% on average) compared with fiber diets $(27.5 \%$ on average). This higher mammary efficiency use of AA with starch diets was accompanied by a greater fractional extraction and clearance rate of AA belonging to group 2 (BCAA, Lys, Thr) by the mammary gland in absence of effects of $\mathrm{CHO}$ on either the mammary blood flow or the mammary AA metabolism. The positive effect of starch diets on mammary clearance
\end{abstract}

Received March 2, 2015

Accepted June 8, 2015.

${ }^{1}$ Corresponding author: gonzalo.cantalapiedra@clermont.inra.fr rate and uptake of BCAA observed in this study was further improved when increasing dietary CP from 12.0 to $16.5 \%$. Concerning the individual AA, Leu was the only whose mammary uptake accounted for a higher proportion of total essential AA in diets based on starch versus fiber and whose mammary uptake to milk output ratio was modified (together with Pro). Diets rich in starch versus fiber improved the mammary AA utilization; however, some $\mathrm{CHO} \times \mathrm{CP}$ interactions on mammary metabolism support the concept of different metabolic pathways by which starch diets improve milk protein yield at the 2 studied CP levels. Results from this study suggest that mammary Leu and glucose metabolism can be modulated by the supply of glucogenic nutrients to the mammary gland.

Key words: mammary gland, glucogenic, amino acid metabolism, efficiency

\section{INTRODUCTION}

Improving milk $\mathrm{N}$ efficiency (MNE), the proportion of feed $\mathrm{N}$ recovered in milk, is an important issue for dairy farms because it may enhance dairy incomes (Godden et al., 2001) and contribute to decrease the $\mathrm{N}$ pollution (Castillo et al., 2001). One of the most effective ways in dairy cattle to increase MNE (Huhtanen and Hristov, 2009), and then to reduce the manure $\mathrm{N}$ output (Yan et al., 2006), is to reduce the dietary CP content. However, low-protein diets may dramatically affect milk protein yield unless other dietary components, such as dietary energy content (Hanigan et al., 1998a) or AA profile (Haque et al., 2015), are concurrently modified.

Results from large data sets (North European data set in Huhtanen and Hristov, 2009) have shown that at similar energy and $\mathrm{N}$ intakes, diets rich in starch promoted higher MNE compared with diets rich in fiber. In this sense, we have recently found that the proportion of feed $\mathrm{N}$ absorbed into the portal vein as total amino acids (TAA), further released to the peripheral tissues and finally used for milk protein yield, was im- 
proved when the main dietary carbohydrate composition $(\mathbf{C H O})$ changed from fiber to starch in iso- $\mathrm{NE}_{\mathrm{L}}$ diets (Cantalapiedra-Hijar et al., 2014b). However, no direct AA-sparing effect of starch diets was found in that study (Cantalapiedra-Hijar et al., 2014b), in line with others (Larsen and Kristensen, 2012). One of the hypotheses arising was that starch diets increased milk $\mathrm{N}$ yield by improving the mammary anabolic use of AA compared with fiber diets, thus reducing the catabolic use of AA by the portal-drained viscera (Hanigan et al., 1998a, 2004) and liver (Reynolds, 2006) and indirectly improving their posthepatic availability.

Glucose availability for mammary metabolism is often considered limiting for lactose and, hence, milk production (Danfaer, 1994). However, increased glucose availability is not always associated with greater lactose synthesis (Lemosquet et al., 2009), as it is also able to increase milk protein yield at isoenergetic and isonitrogenous levels (Hurtaud et al., 2000; Rulquin et al., 2004). Indeed, although AA availability is the main limiting factor for milk protein synthesis (Bequette et al., 1998), the production of milk protein has also been shown to dramatically increase through endocrine signals only (McGuire et al., 1995; Griinari et al., 1997; Mackle et al., 2000). However, AA supply together with endocrine signals prompted by glucogenic nutrients seem to be highly interconnected in pathways involved in milk protein synthesis (Burgos et al., 2010; Bionaz and Loor, 2011), and some interactions between these stimuli have been previously documented at the molecular level (Vinod and Venkatesh, 2009; Burgos et al., 2010; Rius et al., 2010). Hence, a need to assess the effect of $\mathrm{CHO}$ on mammary metabolism at different protein intakes levels exists.

We hypothesized that the profile of nutrients arriving to the mammary gland when changing the main $\mathrm{CHO}$ from fiber to starch would increase the AA utilization by the mammary gland and that this effect would be different according to the protein supply. Thus, the aim of our study was to evaluate the effects of the dietary carbohydrate composition (starch vs. fiber diets) on mammary nutrient flux and milk performances in dairy cows fed isoenergetic diets at low $(12.0 \% \mathrm{CP})$ versus normal $(16.5 \% \mathrm{CP})$ protein levels.

\section{MATERIALS AND METHODS}

Details of this study have been described previously (Cantalapiedra-Hijar et al., 2014b). The experiment was conducted in respect of the national legislation on animal care (Certificate of Authorisation to Experiment on Living Animals, no. 004495, Ministry of Agriculture, Paris, France).

\section{Animals and Experimental Design}

Five multiparous Jersey cows in midlactation, averaging $365 \pm 33 \mathrm{~kg}$ of BW and $78 \pm 12 \mathrm{DIM}$ at the onset of the experiment, were used in a $4 \times 4$ Latin square design, with the fifth cow used as an extra observation in the Latin square. Chronic indwelling catheters were surgically implanted into major splanchnic vessels (including mesenteric artery) before the lactation peak and at least 5 wk before the beginning of the experiment (Cantalapiedra-Hijar et al., 2014b).

Diet composition, chemical composition, and feed values of diets were described in detail in Cantalapiedra-Hijar et al. (2014a). Briefly, 4 iso- $\mathrm{NE}_{\mathrm{L}}$ diets were formulated according to a $2 \times 2$ factorial arrangement of treatments to test 2 different CP contents [12.0 (low $\mathrm{CP}$ ) and $16.5 \%$ (normal CP), meeting 80 and $100 \%$ of MP requirements (INRA, 2007), respectively] and 2 different carbohydrate compositions (350 g of starch and $310 \mathrm{~g}$ of NDF $/ \mathrm{kg}$ of DM for the starch diets, and $45 \mathrm{~g}$ of starch and $460 \mathrm{~g}$ of $\mathrm{NDF} / \mathrm{kg}$ of $\mathrm{DM}$ for the fiber diets), leading to large variations in the profile of absorbed nutrients as outlined in Cantalapiedra-Hijar et al. (2014a).

Each experimental period lasted 28 d. To minimize postprandial variations, feed were offered from automated feeders in equal quantities every $3 \mathrm{~h}$ from $\mathrm{d} 1$ through 24 and hourly after that point. Cows were housed in tiestalls lighted $24 \mathrm{~h} / \mathrm{d}$ and water was freely available to all cows.

\section{Measurements, Sampling, and Laboratory Analysis}

Net fluxes of nutrients, blood gases, and hormones across the mammary gland were measured on d 27 of each 4 -wk period, whereas milk yield was measured and sampled on d 27 and 28. Milk sampling was conducted twice a day at 0600 and $1700 \mathrm{~h}$ for milk composition analysis ( $\mathrm{n}=4$ per treatment and cow), except for milk AA concentration where only the milk sampled at $1700 \mathrm{~h}$ on d 27 was analyzed. The AA composition of the milk protein was analyzed using a HPLC (Alliance System, Waters, Guyancourt, France) following protein hydrolysis with $6 \mathrm{~N} \mathrm{HCl}(24 \mathrm{~h})$. The sulfur AA (i.e., Met and Cys) were separately liberated by oxidation using performic acid before the protein hydrolysis.

Blood was collected hourly from the mesenteric artery [from 1130 to $1630 \mathrm{~h}(\mathrm{n}=6) ; 30 \mathrm{~min}$ before and after each meal] and from the mammary vein by venipuncture [right udder at 1130 and $1530 \mathrm{~h}$; left udder at 1230 and $1630 \mathrm{~h}(\mathrm{n}=4)]$ into 9-mL tubes containing lithium heparin $(5 \mathrm{IU} / \mathrm{mL}$ of blood) to determine glucose, lactate, BHBA, individual AA, VFA, $\mathrm{O}_{2}$, and $\mathrm{CO}_{2}$ concentrations and EDTA-K $(10 \mu \mathrm{L} / \mathrm{mL}$ of blood $)$ to deter- 
mine urea- $\mathrm{N}$, ammonia- $\mathrm{N}$, triglycerides, NEFA, insulin, and IGF-1 concentrations. Sampling procedures and laboratory analysis are detailed in Cantalapiedra-Hijar et al. (2014b). In addition, plasma IGF-1 concentration was determined by RIA (IGF-I RIA-CT; Mediagnost $\mathrm{GmbH}$, Reutlingen, Germany) validated for the bovine.

\section{Calculations and Statistical Analysis}

Whole-blood $\mathrm{O}_{2}$ concentration as well as heat production were calculated as previously detailed (Cantalapiedra-Hijar et al., 2014b), whereas whole-blood $\mathrm{CO}_{2}$ concentration was calculated according to SiggaardAndersen et al. (1988). The arteriovenous concentration (AV) difference of a nutrient, hormone, or blood gas was calculated as its mean arterial concentration $(\mathrm{n}=6)$ minus its mean venous concentration $(\mathrm{n}=$ 4). Mammary plasma flow was calculated by the Fick principle based on uptake and output of Phe and Tyr and using a correction factor of $3.5 \%$ for blood-borne proteins secreted directly in milk (Cant et al., 1993); therefore, mammary plasma flow $=$ (measured milk output of Phe + Tyr $\times 0.965) /($ measured arteriovenous difference of Phe + Tyr). Mammary blood flow was then calculated as mammary plasma flow divided by (1 - hematocrit).

Mammary net uptake of a nutrient, hormone, or blood gas was calculated as its AV difference multiplied by the mammary plasma (or blood) flow. Mammary fractional extraction of a nutrient, hormone or blood gas was calculated as 100 times its AV difference divided by its arterial concentration. Alternatively, to obtain information on the capacity of mammary net transport system, the mammary clearance rate of nutrients was calculated using the model of Hanigan et al. (1998b) as mammary plasma (or blood flow) $\times$ (AV difference) venous concentration). The uptake to milk output ratio of AA, as an indicator of mammary AA metabolism, was calculated as the net uptake of AA by the mammary gland, divided by the measured milk output of AA. Glutamic acid and Gln, as well as Asp and Asn milk output were individually calculated by using the proportion of Glu or Gln and Asp or Asn in milk true protein according to mean literature values reported by Lapierre et al. (2012).

A power test analysis (longpower package; Diggle et al., 2002) from a feeding trial using similar animal and diets as in the present study (pilot study; Cantalapiedra-Hijar et al., 2014a) revealed that to detect an effect of $\mathrm{CHO}$ on MNE (pilot estimate of residual variance), with an effect size of $8 \%$ between starch versus fiber diets (compatible with equations reported in the metaanalysis by Huhtanen and Hristov, 2009), a minimum sample size of 10 individuals per level of $\mathrm{CHO}$ (starch vs. fiber) was required to reach a statistical power of 0.70 at $\alpha=0.05$. However, when the power analysis was carried out for the 2 most important metabolic measurements to be analyzed in the present study (AA and glucose mammary net fluxes of AA and glucose), taking into account residual variances from published data (Lemosquet et al., 2009; Haque et al., 2015), reasonable effect size (20\%; Rulquin et al., 2004; Rius et al., 2010), and sample size equal to 10 individuals per $\mathrm{CHO}$ level, the resulting statistical power ranged from 0.5 to 0.6 .

A linear mixed model using the LME procedure within the nlme package (Pinheiro et al., 2008) in R software (R Development Core Team, 2009) and including a random intercept term for each cow was used. Statistical analyses were carried out as a $4 \times 4$ Latin square, following the model

$$
\begin{aligned}
\mathrm{Y}_{\mathrm{ijk} k}=\mu+ & \mathrm{CHO}_{1}+\mathrm{CP}_{\mathrm{k}}+\mathrm{CHO} \times \mathrm{CP}_{\mathrm{kl}} \\
& +\mathrm{P}_{\mathrm{i}}+\mathrm{C}_{\mathrm{j}}+\varepsilon_{\mathrm{ijk} l},
\end{aligned}
$$

where $Y_{\mathrm{ijkl}}$ is the dependent variable, $\mu$ is the overall mean, $\mathrm{P}_{\mathrm{i}}$ is the fixed effect of the experimental period $\mathrm{i}, \mathrm{C}_{\mathrm{j}}$ is the random effect of cow $\mathrm{j}, \mathrm{CHO}_{1}$ is the fixed effect of dietary carbohydrate composition (starch vs. fiber), $\mathrm{CP}_{\mathrm{k}}$ is the fixed effect of dietary $\mathrm{CP}$ level (low vs. normal), $\mathrm{CHO} \times \mathrm{CP}_{\mathrm{kl}}$ is the fixed effect of the 2-way interaction between $\mathrm{CP}$ and $\mathrm{CHO}$, and $\varepsilon_{\mathrm{ijk} k}$ is the random residual error. Residual normality was verified and confirmed for each variable by applying Shapiro-Wilk test. Mean values are reported as least squares means with pooled standard error of the mean values $(\mathrm{n}=4)$ because of 1 cow $\times$ treatment missing observations (normal CP-starch diet in last period). To assess whether $\mathrm{CHO}$ affected the relationship between the AV difference of EAA and arterial concentration of EAA, an analysis of covariance (ANCOVA) was conducted and slopes and intercepts tested for differences across $\mathrm{CHO}$ (starch vs. fiber). Statistical significance was declared as $P \leq 0.05$ and trends at $P \leq 0.10$. When the $\mathrm{CHO} \times \mathrm{CP}$ was significant, the dietary treatment means were compared using Tukey HSD multiple comparison.

\section{RESULTS}

\section{Milk Yield and Composition}

Milk and ECM yield (Table 1$)$ were not affected $(P$ $\geq 0.65$ ) by $\mathrm{CHO}$, although a tendency for starch diets to promote lower ECM compared with fiber diets was found $(\mathrm{CHO} \times \mathrm{CP} ; P=0.07)$ at normal $(-1.3 \mathrm{~kg})$ but not at low CP levels $(0.8 \mathrm{~kg})$. Milk NPN, CP, and true 
Table 1. Milk yield and composition in lactating Jersey cows fed diets based on either starch or fiber at 2 different dietary CP levels ${ }^{1}$

\begin{tabular}{|c|c|c|c|c|c|c|c|c|}
\hline Item & \multicolumn{2}{|c|}{ Low CP $(12.0 \%)$} & \multicolumn{2}{|c|}{ Normal CP (16.5\%) } & SEM & \multicolumn{3}{|c|}{$P$-value ${ }^{2}$} \\
\hline Milk yield, $\mathrm{kg} / \mathrm{d}$ & 16.4 & 15.4 & 18.6 & 18.9 & 0.41 & 0.65 & $<0.001$ & 0.12 \\
\hline $\mathrm{CP}, \mathrm{g} / \mathrm{kg}$ & 35.9 & 35.3 & 41.0 & 38.4 & 0.64 & 0.007 & $<0.001$ & 0.14 \\
\hline True protein, $\mathrm{g} / \mathrm{kg}$ & 34.7 & 34.2 & 39.3 & 36.9 & 0.60 & 0.006 & $<0.001$ & 0.15 \\
\hline Casein, \% & 81.7 & 82.0 & 79.8 & 82.3 & 0.72 & 0.11 & 0.28 & 0.14 \\
\hline Lactose, $\mathrm{g} / \mathrm{kg}$ & 51.7 & 53.4 & 50.2 & 52.0 & 1.48 & 0.22 & 0.24 & 0.95 \\
\hline $\mathrm{CP}, \mathrm{g} / \mathrm{d}$ & 588 & 536 & 757 & 725 & 22.3 & 0.05 & $<0.001$ & 0.65 \\
\hline True protein, g/d & 569 & 519 & 726 & 696 & 21.4 & 0.05 & $<0.001$ & 0.61 \\
\hline NPN, g/d & 2.93 & 2.75 & 4.89 & 4.43 & 0.20 & 0.09 & $<0.001$ & 0.49 \\
\hline Fat, g/d & $901^{\mathrm{a}}$ & $879^{\mathrm{a}}$ & $939^{\mathrm{a}}$ & $1,039^{\mathrm{b}}$ & 27.8 & 0.20 & 0.009 & 0.05 \\
\hline Lactose, $\mathrm{g} / \mathrm{d}$ & 847 & 825 & 931 & 992 & 26.5 & 0.28 & 0.002 & 0.14 \\
\hline Cys & 8.44 & 8.42 & 8.32 & 8.04 & 0.080 & 0.24 & 0.009 & 0.12 \\
\hline Gly & 22.4 & 21.7 & 21.4 & 21.4 & 0.28 & 0.25 & 0.06 & 0.22 \\
\hline His & 26.8 & 27.0 & 26.5 & 26.6 & 0.37 & 0.32 & 0.35 & 0.87 \\
\hline Ile & 55.4 & 55.8 & 55.5 & 54.9 & 0.72 & 0.79 & 0.46 & 0.46 \\
\hline Leu & 101 & 101 & 98.1 & 99.1 & 1.00 & 0.98 & 0.02 & 0.66 \\
\hline Lys & 87.8 & 86.8 & 86.4 & 86.8 & 1.05 & 0.79 & 0.45 & 0.77 \\
\hline Met & 30.6 & 29.3 & 29.8 & 29.8 & 0.57 & 0.21 & 0.93 & 0.29 \\
\hline Phe & 52.7 & 51.6 & 52.3 & 50.8 & 1.29 & 0.50 & 0.72 & 0.88 \\
\hline Pro & 102 & 105 & 101 & 100 & 1.70 & 0.27 & 0.09 & 0.18 \\
\hline Ser & 60.4 & 59.2 & 59.4 & 58.3 & 0.82 & 0.32 & 0.26 & 0.93 \\
\hline Thr & 47.7 & 46.6 & 47.5 & 46.6 & 0.74 & 0.28 & 0.88 & 0.82 \\
\hline Tyr & 64.1 & 61.2 & 58.5 & 62.6 & 0.87 & 0.36 & 0.04 & 0.003 \\
\hline Val & 70.5 & 70.7 & 70.5 & 70.2 & 0.77 & 0.68 & 0.68 & 0.74 \\
\hline
\end{tabular}

a,b Values within a row with different superscripts differ significantly at $P<0.05$.

${ }^{1}$ Least squares means presented with pooled SEM (given for $\mathrm{n}=4$ ); $\mathrm{n}=5$ for low CP-starch, low CP-fiber, and normal CP-starch and $\mathrm{n}=4$ for normal CP-fiber.

${ }^{2} \mathrm{CHO}=$ effect of dietary carbohydrate (starch vs. fiber); $\mathrm{CP}=$ effect of dietary CP level.

${ }^{3} \mathrm{ECM}=[(0.038 \times \mathrm{g}$ of crude fat $+0.024 \times \mathrm{g}$ of $\mathrm{CP}+0.017 \times \mathrm{g}$ of lactose $) \times \mathrm{kg}$ of milk $] / 3.14$.

protein concentrations and yield were higher $(P \leq 0.09)$ when feeding starch versus fiber diets, but no effect of CHO on MUN was observed $(P=0.85)$. Milk fat and lactose concentrations and yields were unaffected $(P \geq$ 0.12 ) by $\mathrm{CHO}$, although at normal $\mathrm{CP}$ levels milk fat yield was higher when $\mathrm{CHO}$ changed from starch to fiber $(11 \%$; $\mathrm{CHO} \times \mathrm{CP} ; P=0.05)$.

Diets formulated at $16.5 \% \mathrm{CP}$ promoted higher $(P$ $<0.001)$ milk and ECM yield as well as greater $(P<$ 0.001 ) concentration and yield of all analyzed milk $\mathrm{N}$ fractions. Although milk fat and lactose concentration decreased $(P=0.05)$ and remained similar $(P=0.24)$, respectively, milk yield increased $(P \leq 0.009)$ when changing from 12.0 to $16.5 \% \mathrm{CP}$. The casein proportion in milk true protein remained constant $(P=0.11)$ across dietary treatments.

Milk AA composition ( $\mathrm{g} / \mathrm{kg}$ of true protein) was not affected $(P>0.05)$ by $\mathrm{CHO}$, although a tendency for Arg to be higher $(P=0.10)$ for starch versus fiber diets was observed. Conversely, low-CP diets promoted higher $(P \leq 0.10)$ milk concentrations of Cys, Gly, Leu, and Pro compared with normal CP diets. Milk Tyr concentration was higher at low-CP diets, but only with diets rich in starch $(\mathrm{CHO} \times \mathrm{CP} ; P=0.003)$.

\section{Mammary Flow and Arteriovenous Differences}

Mammary plasma and blood flows (Table 2; L/h) were not affected either by $\mathrm{CHO}(P \geq 0.38)$ or $\mathrm{CP}(P \geq$ 0.58). However, as mammary flow rates were expressed per kilogram of milk yield, higher values were obtained $(P \leq 0.05)$ for low- compared with normal CP diets.

Starch diets promoted lower AV difference for acetate $(P=0.02)$, but higher for BHBA $(P=0.04)$ and glucose $(P=0.07)$ compared with fiber diets (Table $3)$. Conversely, AV difference for these 3 nutrients was unaffected $(P \geq 0.20)$ by CP level. Lactate AV difference tended $(P=0.08)$ to be lower with low-CP diets 
Table 2. Mammary plasma and blood flow rates in lactating Jersey cows fed diets based on either starch or fiber at 2 different dietary CP levels ${ }^{1}$

\begin{tabular}{|c|c|c|c|c|c|c|c|c|}
\hline Item & \multicolumn{2}{|c|}{ Low CP (12.0\%) } & \multicolumn{2}{|c|}{ Normal CP $(16.5 \%)$} & SEM & \multicolumn{3}{|c|}{$P$-value ${ }^{2}$} \\
\hline \multicolumn{9}{|c|}{ Mammary plasma flow } \\
\hline $\mathrm{L} / \mathrm{kg}$ of milk & 677 & 884 & 583 & 599 & 77 & 0.14 & 0.04 & 0.22 \\
\hline \multicolumn{9}{|c|}{ Mammary blood flow } \\
\hline $\mathrm{L} / \mathrm{h}$ & 583 & 678 & 597 & 609 & 76 & 0.41 & 0.69 & 0.57 \\
\hline
\end{tabular}

${ }^{1}$ Least squares means presented with pooled SEM (given for $\mathrm{n}=4$ ); $\mathrm{n}=5$ for low CP-starch, low CP-fiber, and normal CP-starch and $\mathrm{n}=4$ for normal CP-fiber.

${ }^{2} \mathrm{CHO}=$ effect of dietary carbohydrate (starch vs. fiber); $\mathrm{CP}=$ effect of dietary $\mathrm{CP}$ level.

compared with normal $\mathrm{CP}$ diets, but unaffected $(P=$ 0.24 ) by $\mathrm{CHO}$. On the contrary, the AV difference of IGF-1 tended $(P=0.06)$ to be lower with normal CP diets (negative values) compared with low-CP diets (positive values). Higher $(P \leq 0.04)$ AV difference of urea-N, TAA, AA belonging to group 1 and 2, EAA, branched-chain AA (BCAA), and NEAA, but not of ammonia-N $(P=0.76)$, were observed with normal versus low-CP diets, all being similar across $\mathrm{CHO}(P$ $\geq 0.20)$.

When the AV difference of EAA across the mammary gland was regressed against their arterial concentration, a significant and positive relationship was found $\left(\mathrm{R}^{2}=0.81 ; P<0.001\right.$, data not shown). The analysis of covariance (Figure 1) showed that starch versus fiber diets promoted higher $(P<0.05)$ AV difference of EAA across the mammary gland when compared at similar EAA arterial concentrations. No effect of either CHO $(P \geq 0.11)$ or $\mathrm{CP}(P \geq 0.16)$ was found on $\mathrm{AV}$ difference of propionate, butyrate, NEFA, triglycerides, $\mathrm{O}_{2}, \mathrm{CO}_{2}$, and insulin, although a tendency $(P=0.09)$ for starch diets to have higher respiratory quotient was noted compared with fiber diets. Similar AV difference between starch and fiber diets was observed $(P>0.10)$ for all individual AA, except for Pro which was higher $(P=0.05)$ with starch versus fiber diets. Conversely, AV difference of all individual AA was greater $(P \leq$ $0.10)$ at normal versus low $\mathrm{CP}$ levels, except $(P \geq 0.11)$ for Ile, Lys, Asn, Glu, Gln, and Gly.

\section{Mammary Net Uptake}

Net fluxes of nutrients and hormones across the mammary gland as well as the calculated mammary heat production are presented in Table 4. Mammary net uptake of acetate was higher $(P=0.04)$ for fiber versus starch diets, whereas that of glucose was lower but only at normal $\mathrm{CP}$ levels $(\mathrm{CHO} \times \mathrm{CP} ; P$ $=0.02$ ). Likewise, when the mammary glucose uptake was expressed per milk lactose output (on a carbon basis) values were higher for starch versus fiber diets, but only at normal $\mathrm{CP}$ levels $(\mathrm{CHO} \times \mathrm{CP} ; P=0.001)$. Mammary net uptake of TAA, EAA, AA belonging to group 2, and BCAA were higher $(P \leq 0.04)$ with starch versus fiber diets, whereas that of ammonia-N, urea-N, AA belonging to group 1 , and NEAA were similar $(P$ $\geq 0.28$ ).

Net uptake of lactate across the mammary gland was different $(P=0.03)$ between low- and normal CP diets, a release of lactate at low $\mathrm{CP}$ and an uptake at normal $\mathrm{CP}$ was observed. Normal CP diets improved $(P \leq 0.08)$ the net mammary uptake of TAA, EAA, AA belonging to group 1 and group 2, BCAA, and NEAA and lowered $(P=0.04)$ that of urea-N compared with low-CP diets. No changes across treatments were observed $(P$ $>0.10)$ when mammary uptake of TAA was expressed per either net portal appearance or splanchnic release of TAA. No differences in mammary net uptake of propionate, butyrate, BHBA, NEFA, triglycerides, insulin, and ammonia-N were observed across either $\mathrm{CHO}(P \geq$ $0.15)$ or $\mathrm{CP}(P \geq 0.17)$ levels. Although heat production by the mammary gland numerically increased with starch versus fiber diets $(17 \%)$, values were not significantly different $(P>0.10)$ across dietary treatments. Shifting from fiber to starch diets, the mammary net uptake increased $(P \leq 0.10)$ for Tyr, Leu, Pro, and Gly, as well as for Thr and Met, but only at low $\mathrm{CP}(\mathrm{CHO} \times$ $\mathrm{CP} ; P \leq 0.08)$. The mammary net uptake of individual AA was greater $(P \leq 0.10)$ at normal versus low $\mathrm{CP}$, except $(P \geq 0.13)$ for His, Asn, Glu, Gln, and Gly. Finally, the profile of AA taken up by the mammary gland (regarded as the relative mammary uptake of a particular AA or group of AA compared with TAA or EAA) was similar $(P>0.05)$ across dietary treatments (data not shown), except for Leu, for which relative mammary uptake increased with starch versus fiber $\operatorname{diets}(P=0.001)$ and with normal versus low-CP diets $(P=0.008)$. 
Table 3. Arteriovenous difference across the mammary gland for nutrients, blood gases and hormones in lactating Jersey cows fed diets based on either starch or fiber at two different dietary CP levels ${ }^{1}$

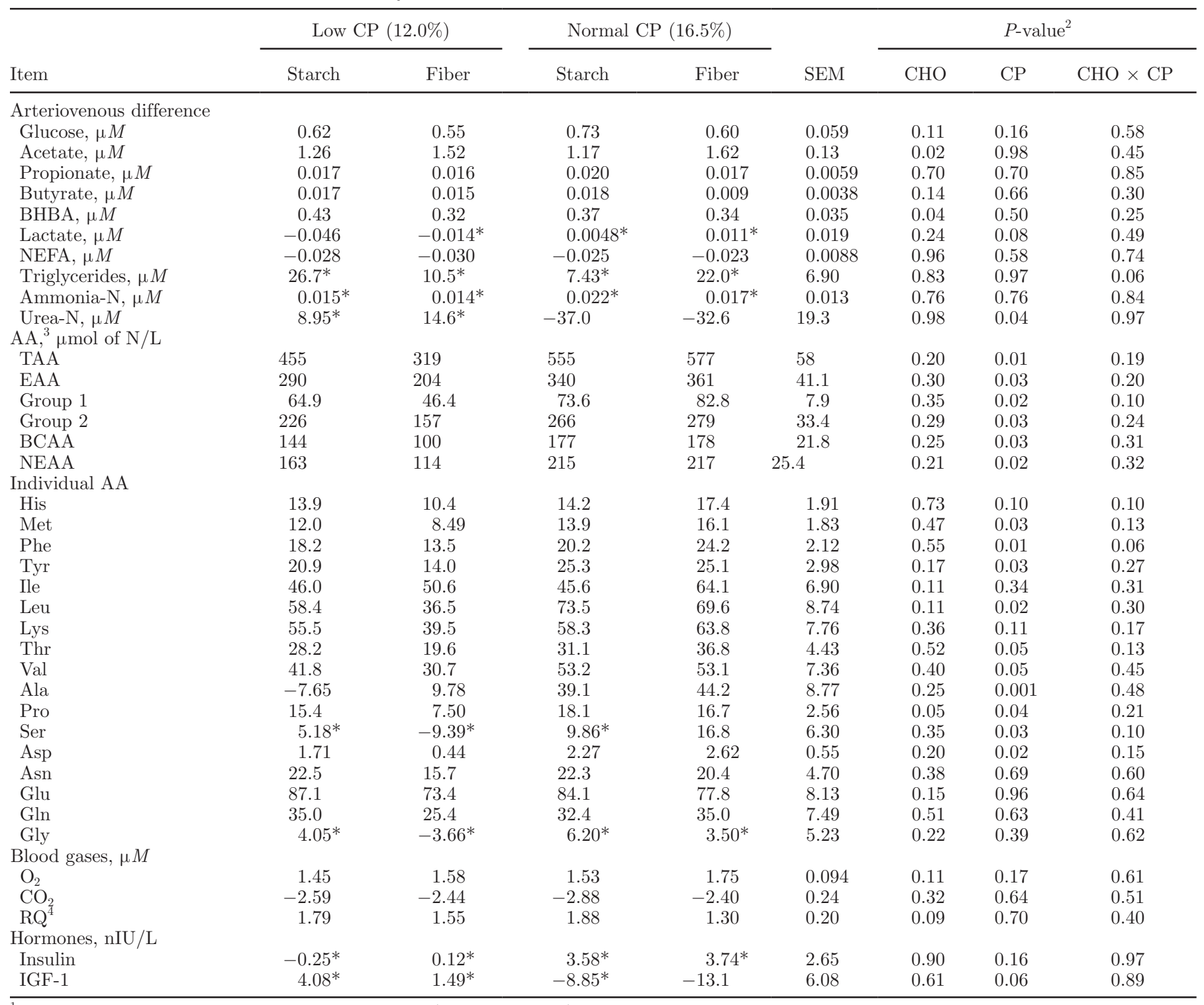

${ }^{1}$ Least squares means presented with pooled SEM (given for $\mathrm{n}=4$ ); $\mathrm{n}=5$ for low CP-starch, low CP-fiber, and normal CP-starch and $\mathrm{n}=4$ for normal CP-fiber.

${ }^{2} \mathrm{CHO}=$ effect of dietary carbohydrate (starch or fiber); $\mathrm{CP}=$ effect of $\mathrm{CP}$.

${ }^{3} \mathrm{TAA}=$ total amino acids (NEAA + EAA); NEAA = Ala, Pro, Ser, Asp, Glu, Asn, Gly, and Gln; EAA = His, Met, Phe, Tyr, Ile, Leu, Lys, Thr, and Val; BCAA = branched-chain AA (Leu, Ile, and Val); Group $1=$ His, Met, Phe and Tyr (Mepham, 1982); Group $2=$ BCAA, Lys and Thr (Mepham, 1982).

${ }^{4}$ Respiratory quotient.

$* P<0.05$.

\section{Fractional Extraction and Clearance Rates of Nutrients by the Mammary Gland}

Mammary fractional extraction and clearance rates of nutrients are presented in Table 5 . Fractional extraction by the mammary gland was improved $(P \leq 0.05)$ for BHBA, EAA, AA belonging to group 2, and BCAA, but not $(P \geq 0.16)$ for lactate, TAA, AA belonging to group 1, and NEAA when CHO changed from fiber to starch. The fractional extraction by the mammary gland was higher $(P \leq 0.03)$ at normal versus low $\mathrm{CP}$ for lactate, TAA, and NEAA, but remained unchanged $(P \geq 0.11)$ for that of BHBA, AA belonging to group 1 and group 2, EAA, and BCAA. No changes in the mammary fractional extraction were observed for other nutrients across either $\mathrm{CHO}(P \geq 0.18)$ or $\mathrm{CP}$ levels $(P$ 


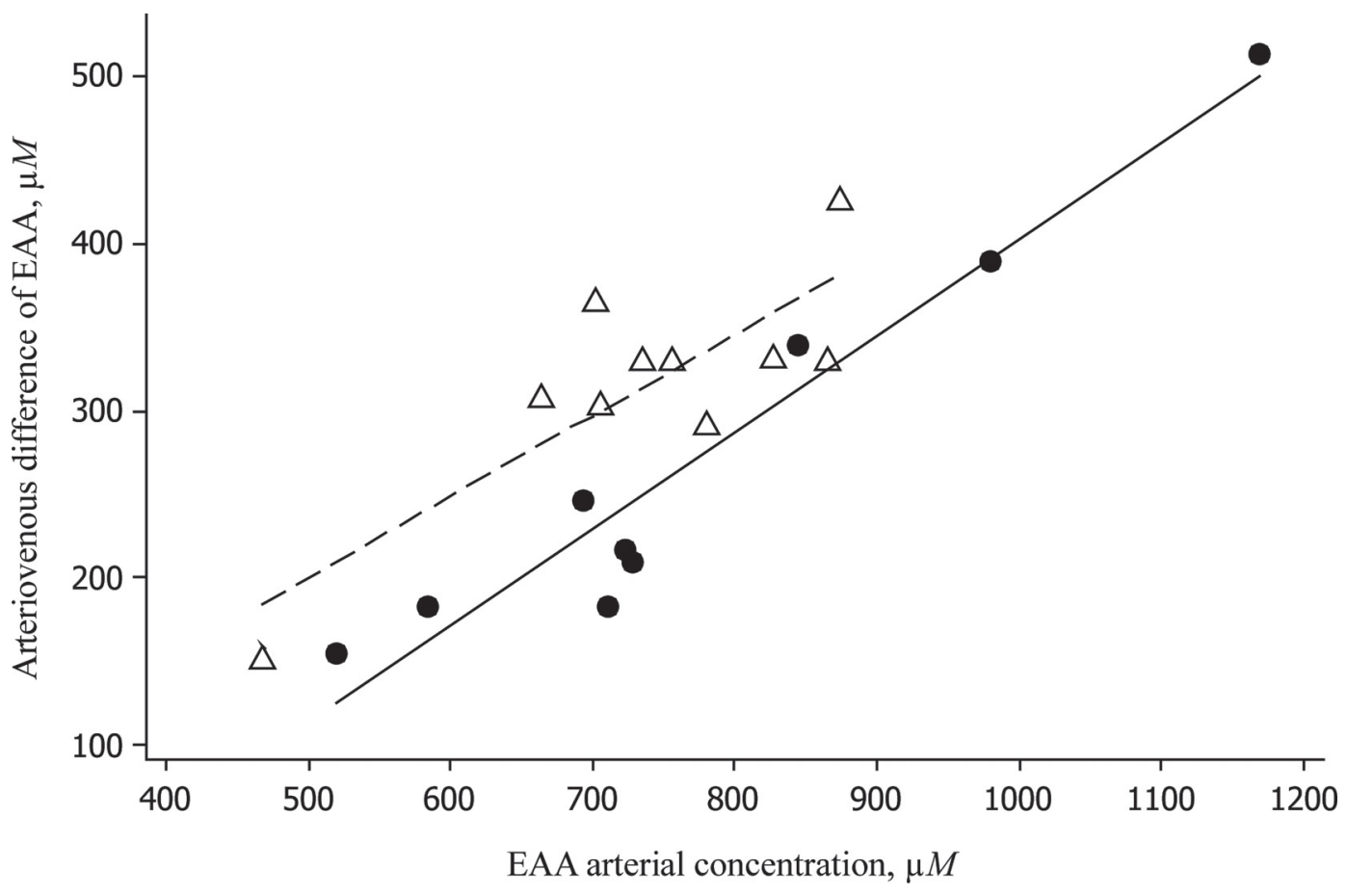

Figure 1. Relationship between mammary arteriovenous difference of EAA and arterial concentration of EAA for starch $(\Delta)$ and fiber $(\bullet)$ diets. Individual values are adjusted for animal and period effects. The analysis of covariance showed that both equations had similar slopes ( 0.485 vs. 0.576 for starch and fiber diets, respectively; $P=0.33)$, but different intercept $(-41.8$ vs. -174 for starch and fiber diets, respectively; $P=0.03)$.

$\geq 0.18)$. The mammary fractional extraction increased $(P \leq 0.09)$ for Met, Phe, Tyr, Ile, and Pro and decreased $(P=0.06)$ for His when feeding starch versus fiber and was greater $(P \leq 0.10)$ for normal versus low-CP diets for most individual AA, except $(P \geq 0.11)$ for Met, Ile, Lys, Val, Asn, Glu, Gln, and Gly.

Similar effects of CHO $(P \leq 0.10)$ on mammary fractional extraction and clearance rates were found for most nutrients. However, as $\mathrm{CHO}$ shifted from fiber to starch, the mammary clearance rate, unlike the fractional extraction, was improved for glucose (at normal but not at low $\mathrm{CP} ; P=0.02)$, TAA $(P=0.02)$, AA belonging to group $1(P=0.002)$, Lys, and Gly $(P=$ $0.08)$, and remained unchanged for BHBA $(P=0.35)$ and Glu $(P=0.16)$. Similarly, when shifting from 12.0 to $16.5 \% \mathrm{CP}$ diets the mammary clearance rate, but not the fractional extraction rate, was improved $(P \leq$ 0.10 ) for AA belonging to group 2, BCAA, Ile, and Asn and remained unchanged for Thr $(P=0.18)$.

\section{AA Inflow to the Mammary Gland and Mammary AA Metabolism}

Amino acid inflow to the mammary gland was not modified by $\mathrm{CHO}(P>0.05)$, although a tendency $(P$ $=0.09)$ for diets rich in starch to promote greater His inflow to the mammary gland and lower of Val and Ile compared with diets rich in fiber was found (Table 6). Increasing the dietary $\mathrm{CP}$ level only improved $(P$ $<0.10)$ the EAA, AA belonging to group 1, and His inflow to the mammary gland and decreased $(P=0.06)$ that of Gly.

The uptake to milk output ratio (Table 6) of all AA was similar $(P>0.10)$ across $\mathrm{CHO}$ [except for Leu and Pro, with higher $(P \leq 0.04)$ values for starch vs. fiber diet] and across CP levels [except for Leu, Ala, and Ser, with higher $(P \leq 0.07)$ values at normal vs. low $\mathrm{CP}$, and Glu with lower $(P=0.01)$ values].

The efficiency of AA use by the mammary gland, defined as the milk output relative to the total mammary inflow, increased $(P \leq 0.10)$ when feeding starch versus fiber diets for EAA, AA belonging to group 2, BCAA, and for Met, Phe, Tyr, Ile, Thr, Val, and Ala. When changing the CP level of diets from 12.0 to $16.5 \%$ this efficiency was also improved $(P \leq 0.10)$ for TAA, AA belonging to group 2, NEAA, and most individual AA, except $(P \geq 0.13)$ for Met, Leu, Lys, Val, and Asp.

\section{DISCUSSION}

The effect of protein supply on mammary metabolism has been previously discussed in other studies (Guinard 
Table 4. Mammary net uptake of nutrients, blood gases, and hormones in lactating Jersey cows fed diets based on either starch or fiber at 2 different dietary CP levels

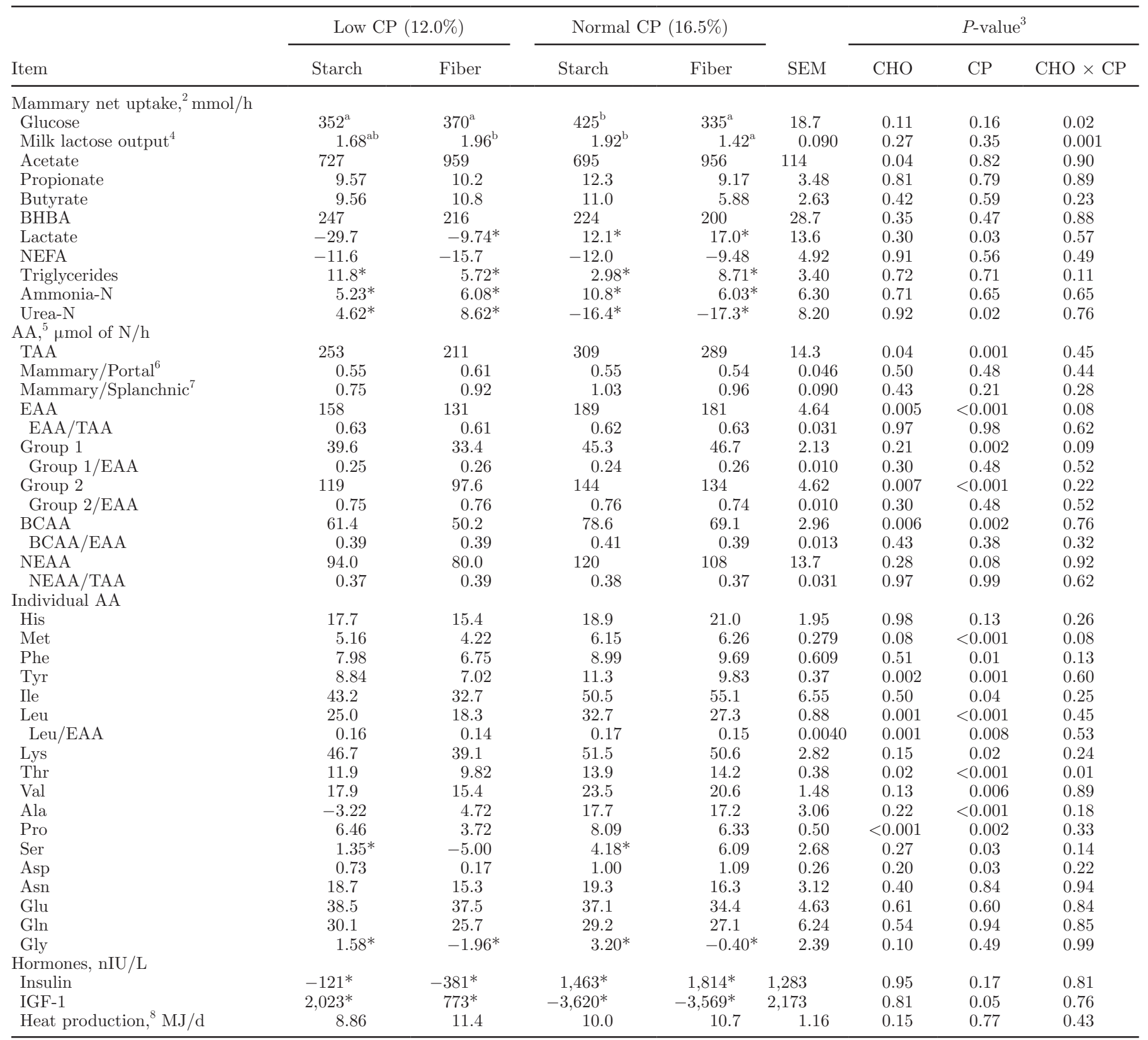

${ }^{1}$ Least squares means presented with pooled SEM (given for $\mathrm{n}=4$ ); $\mathrm{n}=5$ for low CP-starch, low CP-fiber, and normal CP-starch and $\mathrm{n}=4$ for normal CP-fiber.

${ }^{2}$ Mammary net uptake $=$ mammary blood or plasma flow $\times$ arteriovenous difference; a negative value indicates nutrient release rather than uptake.

${ }^{3} \mathrm{CHO}=$ effect of dietary carbohydrate (starch or fiber); $\mathrm{CP}=$ effect of $\mathrm{CP}$.

${ }^{4}$ Calculated on a carbon basis.

${ }^{5} \mathrm{TAA}=$ total amino acids $($ NEAA + EAA) NEAA = Ala, Pro, Ser, Asp, Glu, Asn, Gly, and Gln; EAA = His, Met, Phe, Tyr, Ile, Leu, Lys, Thr, and Val; BCAA = branched-chain AA (Leu, Ile, and Val); Group 1 = His, Met, Phe, and Tyr (Mepham, 1982); Group $2=$ BCAA, Lys, and Thr. ${ }^{6}$ Mammary/Portal = mammary net uptake of total AA divided by net portal appearance of total AA (as reported in Cantalapiedra-Hijar et al., 2014b).

${ }^{7}$ Mammary/Splanchnic $=$ mammary net uptake of total AA divided by net splanchnic release of total AA (as reported in Cantalapiedra-Hijar et al., 2014b).

${ }^{8} \mathrm{Heat}$ production calculated as $4.89 \mathrm{kcal} / \mathrm{L}$ of $\mathrm{O}_{2}$ consumed (McLean, 1972).

${ }^{*} P<0.05$ (probability that the variable is not different from zero within each treatment, tested using Student's $t$-value) 
and Rulquin, 1994; Raggio et al., 2006; Doepel and Lapierre, 2010); hence, the discussion will mainly focus on the effect of dietary carbohydrate composition on mammary metabolism and its possible interaction with the dietary CP level.

\section{Mammary AA Use with Starch Versus Fiber Diets}

Our results show that mammary net uptake of TAA, EAA, and BCAA was significantly enhanced $(12,11$, and $26 \%$ on average, respectively) when feeding starch versus fiber diets, in line with a greater milk protein yield (7\% on average) and regardless of the dietary protein content (i.e., lack of significant $\mathrm{CHO} \times \mathrm{CP}$ interaction). An additive effect of glucogenic substrates and AA supply on milk protein yield has been observed in several experiments carried out in dairy cows (Raggio et al., 2006; Lemosquet et al., 2009; Rius et al., 2010).

In our study, we considered 2 interpretations. First, the positive effect of starch on mammary AA uptake might be interpreted as a consequence of the greater availability of absorbed AA for peripheral tissues (15\% net splanchnic release of total AA; Cantalapiedra-Hijar et al., 2014b). Indeed, no differences were found when mammary TAA uptake was expressed with respect to either net portal appearance or net splanchnic release of TAA. This might indicate that mammary uptake of AA is driven by mass action and that the higher availability of AA for peripheral tissues promoted by starch diets could be the consequence of a higher supply of digestible protein to the small intestine. However, the present experiment also showed that the conversion efficiency of plasma EAA into milk protein (milk EAA output/ mammary EAA inflow; the latter remaining constant across CHO) was improved with starch diets (33.7\% on average) compared with fiber diets (27.5\% on average), in line with a greater clearance rate. Consequently, our results may support the concept that the improvement in mammary AA use could have contributed per se to decrease the splanchnic AA catabolism (Hanigan et al., 1998a, 2004; Reynolds, 2006) and thus to enhance the posthepatic AA availability on a net basis $(22 \%$ net splanchnic release of EAA; Cantalapiedra-Hijar et al., 2014b). Likewise, when the AV difference of EAA across the mammary gland was compared at similar arterial concentrations, starch diets promoted a higher fractional extraction compared with fiber diets (Figure $1)$. These results agree, considering the splanchnic tissues are a responder (to peripheral AA use) rather than a driver of the AA use by peripheral tissues (Reynolds, 2002; Hanigan et al., 2004).

The AA utilization by the mammary gland for milk protein synthesis is under a finely tuned control system (Clark et al., 1978). Based on the balance be- tween supply and requirements, the mammary gland is capable of responding to changes by modulating the fractional extraction (Mackle et al., 2000) or clearance rate (Bequette et al., 2000), the blood flow (Prosser et al., 1996), and the intracellular metabolism of AA (Mepham, 1982). Present results show that the higher mammary efficiency of use of AA with starch versus fiber diets was mainly the consequence of a clearance rate of EAA by the mammary gland in absence of effects of $\mathrm{CHO}$ on either the mammary blood (plasma) flow or the mammary net uptake to milk output ratio of AA. Our results, thus, may suggest that the mammary gland became more sensitive to the supply of EAA when feeding starch versus fiber diets and increased its ability to extract AA from plasma.

The greater fractional extraction and clearance rates of EAA with starch versus fiber diets was mostly accounted for by AA belonging to group 2 (Mepham, 1982; BCAA, Lys, and Thr), whose mammary uptake is usually greater than their milk output (1.4 on average in the present experiment). The metabolism of these particular EAA is crucial for the formation of the intracellular pool of NEAA (Davis and Mepham, 1976), whose mammary uptake ( 0.63 on average in the present experiment) is not adequate to account for the needs of milk protein synthesis. It was noted in our study that the clearance rates of all NEAA (except of Pro), unlike that of most EAA, remained similar between starch and fiber diets. This could imply upregulation for the activity of some AA transport systems [Baumrucker, 1985; L-system (Phe, Tyr, Met, and BCAA) and $\mathrm{y}+\mathrm{L}$ system (Lys), whose clearance rate in the present experiment was improved with starch vs. fiber], but not of others [Baumrucker, 1985; A-system (Pro, Ala, and Gly), N-system (His), ASC-system (Thr and

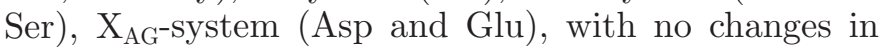
the clearance rate across $\mathrm{CHO}$, except for Pro]. This selective upregulation of AA transporters may be mediated in part by changes in endocrine signaling (Bionaz and Loor, 2011). In this regard, a role of insulin in the cellular metabolism of EAA to meet the requirements of NEAA for milk protein synthesis has been hypothesized (Menzies et al., 2009).

The positive effect of starch diets on mammary gland affinity (regarded as clearance rate) and uptake of BCAA observed in our study was further improved when increasing dietary $\mathrm{CP}$ level $(\mathrm{CHO} \times \mathrm{CP}, P=$ 0.03), thus explaining the $\mathrm{CHO} \times \mathrm{CP}$ interaction also observed for BCAA arterial concentrations [lower $(-23 \%)$ BCAA arterial concentration with starch vs. fiber only at normal CP levels; Cantalapiedra-Hijar et al., 2014b] as well as in other studies infusing glucogenic substrates and casein in dairy cows (Raggio et al., 2006; Rius et al., 2010). In this regard, the expression 
Table 5. Mammary fractional extraction and clearance of nutrients in lactating Jersey cows fed diets based on either starch or fiber at 2 different dietary CP levels ${ }^{1}$

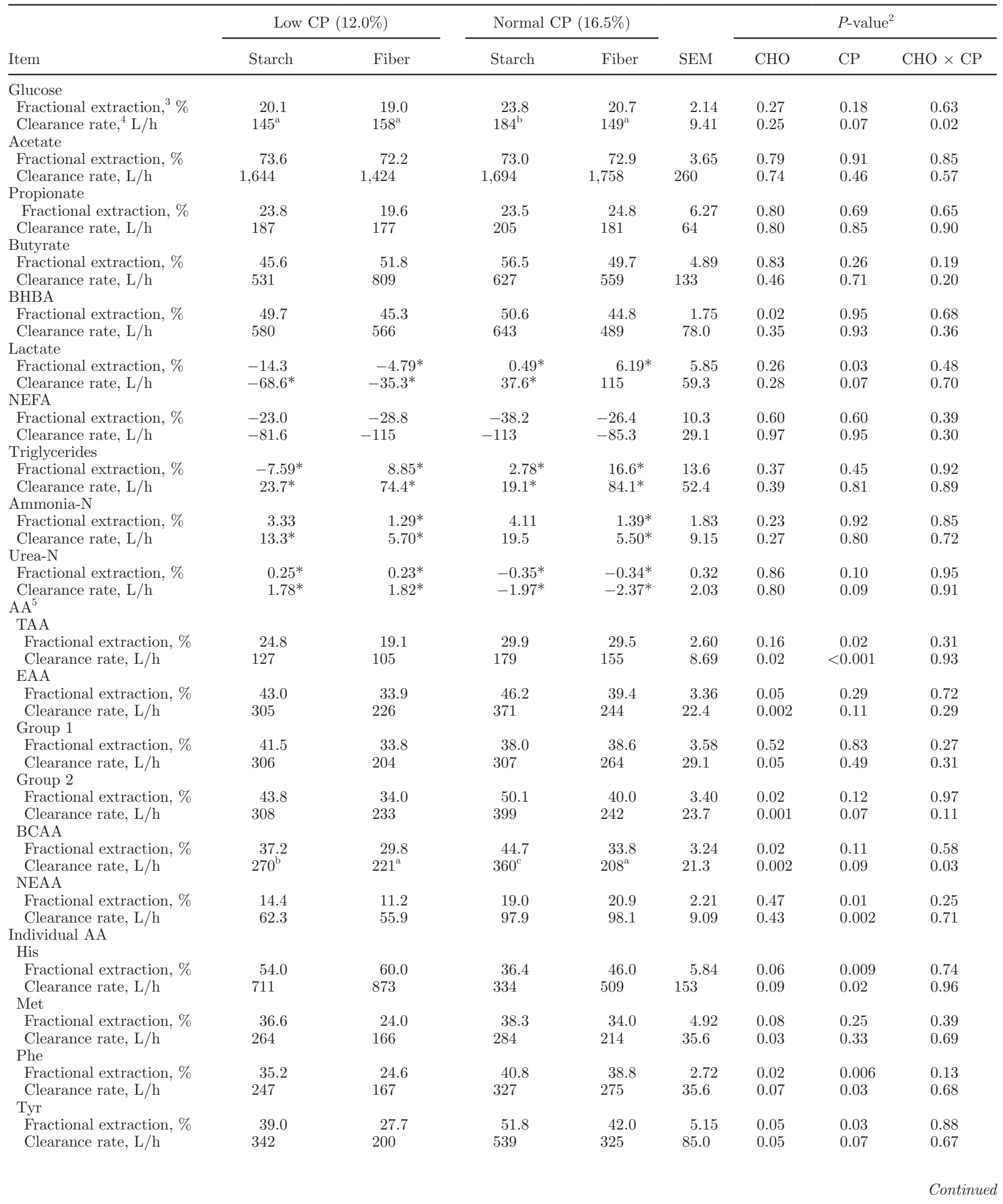


Table 5 (Continued). Mammary fractional extraction and clearance of nutrients in lactating Jersey cows fed diets based on either starch or fiber at 2 different dietary $\mathrm{CP}$ levels ${ }^{1}$

\begin{tabular}{|c|c|c|c|c|c|c|c|c|}
\hline \multirow[b]{2}{*}{ Item } & \multicolumn{2}{|c|}{ Low CP $(12.0 \%)$} & \multicolumn{2}{|c|}{ Normal CP $(16.5 \%)$} & \multirow[b]{2}{*}{ SEM } & \multicolumn{3}{|c|}{$P$-value ${ }^{2}$} \\
\hline & Starch & Fiber & Starch & Fiber & & $\mathrm{CHO}$ & $\mathrm{CP}$ & $\mathrm{CHO} \times \mathrm{CP}$ \\
\hline Fractional extraction, \% & 41.5 & 32.6 & 49.5 & 37.5 & 3.70 & 0.02 & 0.12 & 0.68 \\
\hline Clearance rate, $\mathrm{L} / \mathrm{h}$ & 330 & 250 & 453 & 246 & 33.2 & 0.003 & 0.09 & 0.08 \\
\hline \multicolumn{9}{|l|}{ Leu } \\
\hline Fractional extraction, \% & 42.9 & 39.1 & 53.6 & 42.1 & 3.75 & 0.07 & 0.08 & 0.30 \\
\hline Fractional extraction, $\%$ & 70.4 & 58.9 & 70.4 & 63.3 & 7.00 & 0.30 & 0.98 & 0.74 \\
\hline Clearance rate, $\mathrm{L} / \mathrm{h}$ & 1,285 & 647 & 1,275 & 815 & 242 & 0.08 & 0.97 & 0.71 \\
\hline \multicolumn{9}{|l|}{ Thr } \\
\hline Fractional extraction, $\%$ & 32.1 & 24.1 & 39.0 & 33.7 & 4.70 & 0.12 & 0.08 & 0.78 \\
\hline Clearance rate, $\mathrm{L} / \mathrm{h}$ & 211 & 183 & 290 & 211 & 44.8 & 0.19 & 0.18 & 0.56 \\
\hline \multicolumn{9}{|l|}{ Val } \\
\hline Fractional extraction, \% & 29.1 & 21.7 & 34.0 & 24.7 & 3.28 & 0.04 & 0.33 & 0.76 \\
\hline Fractional extraction, $\%$ & 22.2 & 13.1 & 24.2 & 23.6 & 3.14 & 0.09 & 0.08 & 0.19 \\
\hline Clearance rate, $\mathrm{L} / \mathrm{h}$ & 130 & 77.0 & 143 & 124 & 15.5 & 0.03 & 0.09 & 0.28 \\
\hline \multicolumn{9}{|l|}{ Ser } \\
\hline Fractional extraction, \% & 3.77 & -8.40 & 12.0 & 17.3 & 5.68 & 0.34 & 0.01 & 0.14 \\
\hline Clearance rate, $\mathrm{L} / \mathrm{h}$ & 18.0 & -40.7 & 63.3 & 83.5 & 26.6 & 0.29 & 0.01 & 0.15 \\
\hline \multicolumn{9}{|l|}{ Asp } \\
\hline Fractional extraction, $\%$ & 9.47 & 6.94 & 16.8 & 14.8 & 2.60 & 0.19 & 0.008 & 0.91 \\
\hline Clearance rate, $\mathrm{L} / \mathrm{h}$ & 49.6 & 43.5 & 97.9 & 80.7 & 14.1 & 0.22 & 0.008 & 0.69 \\
\hline \multicolumn{9}{|l|}{ Asn } \\
\hline Fractional extraction, $\%$ & 36.2 & 30.0 & 43.7 & 46.3 & 7.60 & 0.78 & 0.11 & 0.56 \\
\hline Clearance rate, $\mathrm{L} / \mathrm{h}$ & 286 & 215 & 424 & 382 & 89.5 & 0.55 & 0.09 & 0.86 \\
\hline \multicolumn{9}{|l|}{ Glu } \\
\hline Fractional extraction, $\%$ & 35.8 & 27.2 & 33.3 & 30.6 & 2.44 & 0.02 & 0.94 & 0.24 \\
\hline \multicolumn{9}{|l|}{ Gln } \\
\hline \multicolumn{9}{|l|}{ Gly } \\
\hline
\end{tabular}

\footnotetext{
a,b Values within a row with different superscripts differ significantly at $P<0.05$

${ }^{1}$ Least squares means presented with pooled SEM (given for $\mathrm{n}=4$ ); $\mathrm{n}=5$ for low CP-starch, low CP-fiber, and normal CP-starch and $\mathrm{n}=4$ for normal CP-fiber.

${ }^{2} \mathrm{CHO}=$ effect of dietary carbohydrate (starch or fiber); $\mathrm{CP}=$ effect of $\mathrm{CP}$.

${ }^{3}$ Fractional extraction $=[$ arteriovenous difference/arterial concentration $] \times 100$.

${ }^{4}$ Clearance rate $=$ mammary blood or plasma flow $\times$ (arteriovenous difference/venous concentration $)$.

${ }^{5} \mathrm{TAA}=$ total amino acids (NEAA + EAA); NEAA = Ala, Pro, Ser, Asp, Glu, Asn, Gly, and Gln; EAA = His, Met, Phe, Tyr, Ile, Leu, Lys, Thr, and Val; BCAA = branched-chain AA (Leu, Ile, and Val); Group 1 = His, Met, Phe, and Tyr (Mepham, 1982); Group $2=$ BCAA, Lys, and Thr. ${ }^{*} P<0.05$ (probability that the variable is not different from zero within each treatment, tested using Student's $t$-value).
}

of mammary tissue proteins involved in the transport of BCAA appears to be under control of the mammalian target of rapamycin (mTOR) pathway (Bionaz and Loor, 2011), which is activated via the insulin signaling cascade and seems to be modulated by the level of AA supply (Burgos et al., 2010; Rius et al., 2010). As discussed in next section, the AA supply and insulin concentration seemed to interact on mammary glucose and BCAA (Leu) metabolism in our study.

\section{Mammary Response to Nutrient Supply and Endocrine Signals}

As expected, the nature of nutrients taken up by the mammary gland differed between starch and fiber diets was revealed by differences in the calculated respiratory quotient (1.84 vs. 1.43 , respectively, on average). In particular, acetate net uptake increased $(35 \%$ on average) with fiber versus starch diets, likely driven by 
Table 6. Mammary inflow, uptake to output ratio and efficiency use of AA in dairy cows fed diets based on either starch or fiber at 2 different dietary CP levels ${ }^{1}$

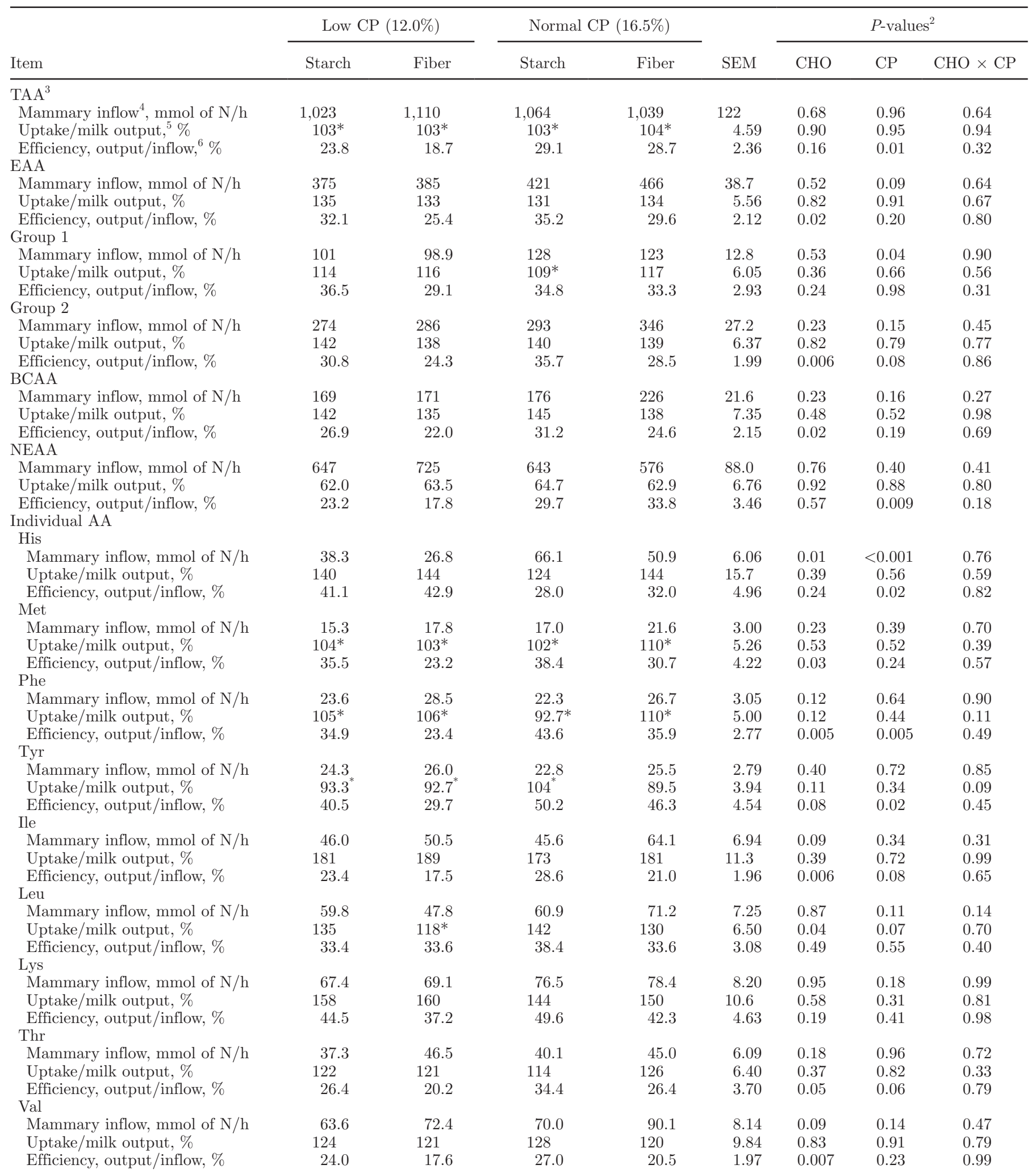


Table 6 (Continued). Mammary inflow, uptake to output ratio and efficiency use of AA in dairy cows fed diets based on either starch or fiber at 2 different dietary $\mathrm{CP}$ levels ${ }^{1}$

\begin{tabular}{|c|c|c|c|c|c|c|c|c|}
\hline Item & \multicolumn{2}{|c|}{ Low CP (12.0\%) } & \multicolumn{2}{|c|}{ Normal CP $(16.5 \%)$} & SEM & \multicolumn{3}{|c|}{$P$-values ${ }^{2}$} \\
\hline \multicolumn{9}{|l|}{ Ala } \\
\hline Uptake/milk output, \% & -39.1 & $50.6^{*}$ & $145^{*}$ & $149^{*}$ & 30.4 & 0.11 & 0.002 & 0.17 \\
\hline Efficiency, output/inflow, \% & 10.6 & 8.10 & 14.9 & 12.7 & 1.12 & 0.03 & 0.003 & 0.92 \\
\hline \multicolumn{9}{|l|}{ Pro } \\
\hline \multicolumn{9}{|l|}{ Ser } \\
\hline Mammary inflow, mmol of $\mathrm{N} / \mathrm{h}$ & 50.4 & 54.7 & 46.6 & 38.3 & 7.47 & 0.96 & 0.17 & 0.39 \\
\hline Uptake/milk output, $\%$ & 4.57 & -41.3 & 26.5 & 37.6 & 18.9 & 0.25 & 0.02 & 0.15 \\
\hline Efficiency, output/inflow, \% & 29.0 & 21.7 & 40.0 & 42.8 & 4.46 & 0.37 & 0.005 & 0.26 \\
\hline \multicolumn{9}{|l|}{ Asp } \\
\hline Mammary inflow, mmol of $\mathrm{N} / \mathrm{h}$ & 8.01 & 7.94 & 8.90 & 8.90 & 1.64 & 0.79 & 0.70 & 0.98 \\
\hline Efficiency, output/inflow, \% & 81.1 & 67.9 & 101 & 136 & 21.5 & 0.81 & 0.05 & 0.26 \\
\hline \multicolumn{9}{|l|}{ Glu } \\
\hline Mammary inflow, mmol of $\mathrm{N} / \mathrm{h}$ & 110 & 138 & 114 & 116 & 18.7 & 0.35 & 0.68 & 0.49 \\
\hline Uptake/milk output, $\%$ & 266 & 304 & 202 & 202 & 26.8 & 0.52 & 0.01 & 0.48 \\
\hline Efficiency, output/inflow, \% & 19.5 & 12.5 & 22.9 & 24.1 & 3.20 & 0.27 & 0.04 & 0.21 \\
\hline \multicolumn{9}{|l|}{ Gln } \\
\hline Mammary inflow, mmol of $\mathrm{N} / \mathrm{h}$ & 142 & 170 & 152 & 132 & 28.4 & 0.81 & 0.72 & 0.39 \\
\hline Uptake/milk output, $\%$ & $98.2^{*}$ & $101^{*}$ & $73.7^{*}$ & $77.4^{*}$ & 16.6 & 0.90 & 0.20 & 0.97 \\
\hline Efficiency, output/inflow, \% & 22.8 & 17.2 & 27.2 & 36.7 & 5.44 & 0.83 & 0.06 & 0.18 \\
\hline \multicolumn{9}{|l|}{ Gly } \\
\hline Mammary inflow, mmol of $\mathrm{N} / \mathrm{h}$ & 165 & 176 & 149 & 125 & 16.7 & 0.82 & 0.06 & 0.29 \\
\hline Uptake/milk output, \% & 18.7 & -38.8 & 34.7 & -8.77 & 28.3 & 0.06 & 0.43 & 0.80 \\
\hline Efficiency, output/inflow, $\%$ & 4.53 & 3.55 & 6.07 & 7.75 & 0.71 & 0.87 & 0.003 & 0.08 \\
\hline
\end{tabular}

${ }^{1}$ Least squares means presented with pooled SEM (given for $\mathrm{n}=4$ ); $\mathrm{n}=5$ for low CP-starch, low CP-fiber, and normal CP-starch and $\mathrm{n}=4$ for normal CP-fiber.

${ }^{2} \mathrm{CHO}=$ effect of dietary carbohydrate (starch or fiber); $\mathrm{CP}=$ effect of $\mathrm{CP}$.

${ }^{3} \mathrm{TAA}=$ total amino acids (NEAA + EAA); NEAA = Ala, Pro, Ser, Asp, Glu, Asn, Gly, and Gln; EAA = His, Met, Phe, Tyr, Ile, Leu, Lys, Thr, and Val; BCAA = branched-chain AA (Leu, Ile, and Val); Group 1 = His, Met, Phe, and Tyr (Mepham, 1982); Group 2 = BCAA, Lys, and Thr.

${ }^{4}$ Total inflow $=$ arterial concentration $\times$ mammary plasma flow.

${ }^{5}$ Fractional extraction $=[$ arteriovenous difference/arterial concentration $] \times 100$.

${ }^{6}$ Clearance rate $=$ mammary blood or plasma flow $\times$ (arteriovenous difference/venous concentration $)$.

${ }^{*} P<0.05$ (probability that the variable is not different from $100 \%$ within each treatment, tested using Student's $t$-value).

mass action $(47 \%$ higher total acetate inflow with fiber vs. starch; data not shown), as previously suggested (Cant et al., 1993). Conversely, glucose net uptake, in line with its mammary clearance rate, increased with starch versus fiber diets, but only at normal CP levels (34\%). Glucose uptake by the mammary gland has been unrelated to its arterial concentration in different studies (Cant et al., 1993; Lemosquet et al., 2009) and has been proposed to be regulated, in part, by factors within the mammary gland (Madsen et al., 1999). The observed $\mathrm{CHO} \times \mathrm{CP}$ interaction in the present study on net uptake and clearance rate of glucose, as well as in the clearance rate of BCAA, may suggest an interconnection between glucose uptake and protein synthesis via the mTOR signaling pathway (Bionaz and
Loor, 2011). It is already known that the activation of mTOR complex increases expression of glucose transporters (GLUT1 expression; Bionaz and Loor, 2011), the former being strongly regulated by the BCAA, in particular Leu (Kimball and Jefferson, 2006) and insulin concentrations (Menzies et al., 2009). In this regard, Leu was the only AA whose net uptake accounted for a higher proportion of total EAA in diets based on starch versus fiber, no other differences in the profile of AA taken up by the mammary gland were found in the present experiment (data not shown). In addition, the intramammary AA metabolism, regarded as the uptake to milk output ratio of AA, was only modified by $\mathrm{CHO}$ for Leu (139 vs. 124 on average) and not for any other individual AA, except Pro. Conversely, the mammary 
efficiency use of AA (milk output/mammary inflow) increased for most EAA, except for Leu (as well as Lys and His). These results suggest that mammary uptake of Leu could modulate and be modulated by the protein synthesis signaling cascade rather than driven by a real mammary Leu requirement, as suggested by Bionaz and Loor (2011). In this regard, glutamate released by transamination during mammary BCAA catabolism may be used for the synthesis of Gln, Ala, Asp, and Asn (Li et al., 2009). In our conditions, however, only the mammary efficiency use of Ala increased among the NEAA.

Different studies demonstrated that the production of milk protein can be dramatically increased by altering the endocrine signals (Griinari et al., 1997; McGuire et al., 1995; Mackle et al., 2000). In the present experiment, the increased mammary EAA capture (regarded as clearance rate) and milk protein yield with starch versus fiber diets were consistent with the greater arterial insulin concentration (23\%, on average). In this regard, a $15 \%$ increase in milk protein yield was found when using a hyperinsulinemic-euglycemic clamp in dairy cows (Mackle et al., 2000); more importantly, in our study this was associated to a higher extraction rate of EAA [mainly BCAA (48\%)] rather than to a greater uptake to milk output ratio of EAA. Some other studies (Rius et al., 2010; Rulquin et al., 2004) have also suggested that insulin may play a role in milk protein production and efficiency use of AA; this improvement seems to be supported by an increase in the mammary affinity for some EAA.

A potentiating effect of insulin on BCAA effects may exist. In other studies involving infusion of insulin, plasma concentrations of AA are reduced, with the BCAA being most reduced (McGuire et al., 1995; Griinari et al., 1997; Mackle et al., 2000; Bequette et al., 2001). This was observed in our experiment for starch diets, but only at normal $\mathrm{CP}$ levels $(\mathrm{CHO} \times \mathrm{CP} ; P=0.03)$ corresponding to the highest arterial concentration of insulin. Rius et al. (2010) also found a tendency $(P=$ $0.10)$ for dairy cows infused with starch to have lower BCAA arterial concentrations at high versus low AA supply (with or without casein infusion), an interaction which was significant for Leu $(P=0.01)$. These authors stated that cell-signaling molecules involved in the regulation of protein synthesis differentially responded to these nutritional stimuli (glucogenic substrates and AA supplies).

\section{CONCLUSIONS}

At similar energy intakes, the mammary gland of cows receiving diets rich in starch compared with diets rich in fiber showed a higher affinity (clearance rate) for EAA, leading to a higher efficiency of AA utilization (milk output/total inflow) and milk protein yield. This positive effect of starch was evident both at low $(12.0 \% \mathrm{CP})$ and normal (16.5\% CP) protein levels; thus, additive and independent effects of glucogenic nutrients and AA supplies can be proposed. However, in our study, some interactions between the dietary carbohydrate composition and the protein content of diets on mammary uptake and clearance rates of some nutrients (namely glucose and BCAA) support the concept of different metabolic pathways, likely related to insulin and mTOR signaling pathway, by which starch diets improve milk protein yield at the 2 studied dietary protein content levels. A modulation of mammary Leu and glucose metabolism mediated by glucogenic nutrients (via insulinemia) can be proposed from present results.

\section{ACKNOWLEDGMENTS}

G. Cantalapiedra-Hijar gratefully acknowledges the receipt of a scholarship from PHASE department (INRA). We thank the Commission of the European Communities (Brussels, Belgium; project FP7-KBBE-2007-1 "Rednex") and Adisseo (Commentry, France) for financial support; D. Durand and P. Gaydier (UMR 1213 INRA-VetAgroSup) for animal surgery; C. Chantelauze, A. S. Bage, V. Largeau, A. Thomas, S. Rudel, D. Roux, C. Mathevon, J. B. Temma, L. Mouly, J. M. Rodriguez-Lopez, (all from UMR 1213 INRA-VetAgroSup) and D. Rémond (UMR 1019 INRA-Université Clermont 1) and C. Mustière (from UMR 1348 PEGASE) for animal surgery and technical assistance, respectively.

\section{REFERENCES}

Baumrucker, C. R. 1985. Amino acid transport systems in bovine mammary tissue. J. Dairy Sci. 68:2436-2451.

Bequette, B. J., F. R. C. Backwell, and L. A. Crompton. 1998. Current concepts of amino acid and protein metabolism in the mammary gland of the lactating ruminant. J. Dairy Sci. 81:2540-2559.

Bequette, B. J., M. D. Hanigan, A. G. Calder, C. K. Reynolds, G. E. Lobley, and J. C. MacRae. 2000. Amino acid exchange by the mammary gland of lactating goats when histidine limits milk production. J. Dairy Sci. 83:765-775.

Bequette, B. J., C. E. Kyle, L. A. Crompton, V. Buchan, and M. D. Hanigan. 2001. Insulin regulates milk production and mammary gland and hind-leg amino acid fluxes and blood flow in lactating goats. J. Dairy Sci. 84:241-255.

Bionaz, M., and J. J. Loor. 2011. Gene networks driving bovine mammary protein synthesis during the lactation cycle. Bioinform. Biol. Insights 5:83-98.

Burgos, S. A., M. Dai, and J. P. Cant. 2010. Nutrient availability and lactogenic hormones regulate mammary protein synthesis through the mammalian target of rapamycin signaling pathway. J. Dairy Sci. 93:153-161.

Cant, J. P., E. J. DePeters, and R. L. Baldwin. 1993. Mammary amino acid utilization in dairy cows fed fat and its relationship to milk protein depression. J. Dairy Sci. 76:762-774.

Cantalapiedra-Hijar, G., S. Lemosquet, J. M. Rodriguez-Lopez, F. Messad, and I. Ortigues-Marty. 2014b. Diets rich in starch increase 
the posthepatic availability of amino acids in dairy cows fed diets at low and normal protein levels. J. Dairy Sci. 97:5151-5166.

Cantalapiedra-Hijar, G., J. L. Peyraud, S. Lemosquet, E. Molina-Alcaide, H. Boudra, P. Nozière, and I. Ortigues-Marty. 2014a. Dietary carbohydrate composition modifies the milk $\mathrm{N}$ efficiency in late lactation cows fed crude protein diets. Animal 8:275-285.

Castillo, A. R., E. Kebreab, D. E. Beever, J. H. Barbi, J. D. Sutton, H. C. Kirby, and J. France. 2001. The effect of protein supplementation on nitrogen utilization in lactating dairy cows fed grass silage diets. J. Anim. Sci. 79:247-253.

Clark, J. H., H. R. Spires, and C. L. Davis. 1978. Uptake and metabolism of nitrogenous components by the lactating mammary gland. Fed. Proc. 37:1233-1238.

Danfaer, A. 1994. Nutrient metabolism and utilization in the liver. Livest. Prod. Sci. 34:115-127.

Davis, S. R., and T. B. Mepham. 1976. Metabolism of L-(U-14C) valine, L-(U-14C) leucine, L-(U-14C) histidine and L-(U-14C) phenylalanine by the isolated perfused lactating guinea-pig mammary gland. Biochem. J. 156:553-560.

Diggle, P., P. Heagerty, K. Y. Liang, and S. Zeger. 2002. Analysis of Longitudinal Data. Oxford University Press, Oxford, UK.

Doepel, L., and H. Lapierre. 2010. Changes in production and mammary metabolism of dairy cows in response to essential and nonessential amino acid infusions. J. Dairy Sci. 93:3264-3274.

Godden, S. M., K. D. Lissemore, D. F. Kelton, K. E. Leslie, J. S. Walton, and J. H. Lumsden. 2001. Relationships between milk urea concentrations and nutritional management, production, and economic variables in Ontario dairy herds. J. Dairy Sci. 84:11281139.

Griinari, J. M., M. A. McGuire, D. A. Dwyer, D. E. Bauman, D. M. Barbano, and W. A. House. 1997. The Role of insulin in the regulation of milk protein synthesis in dairy cows. J. Dairy Sci. 80:2361-2371.

Guinard, J., and H. Rulquin. 1994. Effect of graded levels of duodenal infusions of casein on mammary uptake in lactating cows. 2. Individual amino acids. J. Dairy Sci. 77:3304-3315.

Hanigan, M. D., J. P. Cant, D. C. Weakley, and J. L. Beckett. 1998a. An evaluation of postabsorptive protein and amino acid metabolism in the lactating dairy cow. J. Dairy Sci. 81:3385-3401.

Hanigan, M. D., J. France, D. Wray-Cahen, D. E. Beever, G. E. Lobley, L. Reutzel, and N. E. Smith. 1998b. Alternative models for analyses of liver and mammary transorgan metabolite extraction data. Br. J. Nutr. 79:63-78.

Hanigan, M. D., C. K. Reynolds, D. J. Humphries, B. Lupoli, and J. D. Sutton. 2004. A model of net amino acid absorption and utilization by the portal-drained viscera of the lactating dairy cow. J. Dairy Sci. 87:4247-4268.

Haque, M. N., J. Guinard-Flament, P. Lamberton, C. Mustière, and S. Lemosquet. 2015. Changes in mammary metabolism in response to the provision of an ideal amino acid profile at 2 levels of metabolizable protein supply in dairy cows: Consequences on efficiency. J. Dairy Sci. 98:3951-3968. 10.3168/jds.2014-8656.

Huhtanen, P., and A. N. Hristov. 2009. A meta-analysis of the effects of dietary protein concentration and degradability on milk protein yield and milk $\mathrm{N}$ efficiency in dairy cows. J. Dairy Sci. 92:3222-3232.

Hurtaud, C., S. Lemosquet, and H. Rulquin. 2000. Effect of graded duodenal infusions of glucose on yield and composition of milk from dairy cows. 2. Diets based on grass silage. J. Dairy Sci. 83:2952-2962.

INRA. 2007. Alimentation des bovins, ovins et caprins-Besoins des animaux-Valeurs des aliment-Tables INRA 2007. INRA, Versailles, France.

Kimball, S. R., and L. S. Jefferson. 2006. Signaling pathways and molecular mechanisms through which branched-chai amino acids mediate translational control of protein synthesis. J. Nutr. $136: 227 \mathrm{~S}-231 \mathrm{~S}$.

Lapierre, H., G. E. Lobley, L. Doepel, G. Raggio, H. Rulquin, and S. Lemosquet. 2012. Triennial lactation symposium: Mammary metabolism of amino acids in dairy cows. J. Anim. Sci. 90:1708-1721.

Larsen, M., and N. B. Kristensen. 2012. Effects of glucogenic and ketogenic feeding strategies on splanchnic glucose and amino acid metabolism in postpartum transition Holstein cows. J. Dairy Sci. 95:5946-5960.

Lemosquet, S., G. Raggio, G. E. Lobley, H. Rulquin, J. Guinard-Flament, and H. Lapierre. 2009. Whole-body glucose metabolism and mammary energetic nutrient metabolism in lactating dairy cows receiving digestive infusions of casein and propionic acid. J. Dairy Sci. 92:6068-6082.

Li, P., D. A. Knabe, S. W. Kim, C. J. Lynch, S. M. Hutson, and G. Wu. 2009. Lactating porcine mammary tissue catabolizes branched-chain amino acids for glutamine and aspartate synthesis. J. Nutr. 139:1502-1509.

Mackle, T. R., D. A. Dwyer, K. L. Ingvartsen, P. Y. Chouinard, D. A. Ross, and D. E. Bauman. 2000. Effects of insulin and postruminal supply of protein on use of amino acids by the mammary gland for milk protein synthesis. J. Dairy Sci. 83:93-105.

Madsen, T. G., L. Misciattelli, and M. O. Nielsen. 1999. Effect of amino acid versus propionic acid absorption on the supply and uptake of amino acids and glucose by the mammary gland of dairy cows. Page 82 in the VIIIth International Symposium on Protein Metabolism and Nutrition. Aberdeen, UK. Wageningen Pers, Wageningen, the Netherlands.

McGuire, M. A., J. M. Griinari, D. A. Dwyer, and D. E. Bauman. 1995. Role of insulin in the regulation of mammary synthesis of fat and protein. J. Dairy Sci. 78:816-824.

McLean, J. A. 1972. On the calculation of heat production from opencircuit calorimetric measurements. Br. J. Nutr. 27:597-600.

Menzies, K. K., C. Lefèvre, K. L. Macmillan, and K. R. Nicholas. 2009. Insulin regulates milk protein synthesis at multiple levels in the bovine mammary gland. Funct. Integr. Genomics 9:197-217.

Mepham, T. B. 1982. Amino acid utilization by lactating mammary gland. J. Dairy Sci. 65:287-298.

Pinheiro, J. C., and D. M. Bates. S. DebRoy, D. Sarkar, and R Core team. 2008. nlme: Linear and nonlinear mixed effects models. $\mathrm{R}$ package version 3.1-89. R Foundation for Statistical Computing, Vienna, Austria.

Prosser, C. G., S. R. Davis, V. C. Farr, and P. Lacasse. 1996. Regulation of blood flow in the mammary microvasculature. J. Dairy Sci. 79:1184-1197.

R Development Core Team. 2009. R: A language and environment for statistical computing. Accessed Oct. 10, 2014. http://www.Rproject.org.

Raggio, G., S. Lemosquet, G. E. Lobley, H. Rulquin, and H. Lapierre. 2006. Effect of casein and propionate supply on mammary protein metabolism in lactating dairy cows. J. Dairy Sci. 89:4340-4351.

Reynolds, C. K. 2002. Economics of visceral energy metabolism in ruminants: Toll keeping or internal revenue service. J. Anim. Sci. 80:2997-3010.

Reynolds, C. K. 2006. Splanchnic amino acid metabolism in ruminants. Pages 225-248 in Ruminant Physiology: Digestion, Metabolism and Impact of Nutrition on Gene Expression, Immunology and Stress. K. Sejrsen, T. Hvelplund, and M. O. Nielsen, ed. Wageningen Academic Publishers, Wageningen, the Netherlands.

Rius, A. G., J. A. D. R. N. Appuhamy, J. Cyriac, D. Kirovski, O. Becvar, J. Escobar, M. L. McGilliard, B. J. Bequette, R. M. Arkers, and M. D. Hanigan. 2010. Regulation of protein synthesis in mammary glands of lactating dairy cows by starch and amino acids. J. Dairy Sci. 93:3114-3127.

Rulquin, H., S. Rigout, S. Lemosquet, and A. Bach. 2004. Infusion of glucose directs circulating amino acids to the mammary gland in well-fed dairy cows. J. Dairy Sci. 87:340-349.

Siggaard-Andersen, O., P. D. Wimberley, N. Fogh-Andersen, and I. H. Gothgen. 1988. Measured and derived quantities with modern $\mathrm{pH}$ and blood gas equipment: Calculation algorithms with 54 equations. Scand. J. Clin. Lab. Invest. 48:7-15. http://dx.doi. org $/ 10.1080 / 00365518809168181$.

Vinod, P. K. U., and K. V. Venkatesh. 2009. Quantification of the effect of amino acids on an integrated mTOR and insulin signaling pathway. Mol. Biosyst. 5:1163-1173.

Yan, T., J. P. Frost, R. E. Agnew, R. C. Binnie, and C. S. Mayne. 2006. Relationships among manure nitrogen output and dietary and animal factors in lactating dairy cows. J. Dairy Sci. 89:3981-3991. 